Review

\title{
The Fossil Record of Darkling Beetles (Insecta: Coleoptera: Tenebrionidae)
}

\author{
Maxim V. Nabozhenko ${ }^{1,2}$ (D) \\ 1 Precaspian Institute of Biological Resources of the Daghestan Federal Research Centre of the Russian \\ Academy of Sciences, 367000 Makhachkala, Republic of Dagestan, Russia; nalassus@mail.ru \\ 2 Department of biologi and biodiversity, Dagestan State University, \\ 367000 Makhachkala, Republic of Dagestan, Russia
}

Received: 19 October 2019; Accepted: 3 December 2019; Published: 13 December 2019

check for updates

\begin{abstract}
The fossil record of Tenebrionidae (excluding the Quartenary) is presented. In total, 122 fossil species, clearly belonging to the family, are known; some beetles were determined only to genus; 78 genera are listed in the fossil record, including 29 extinct genera. The great diversity of tenebrionids occurs in the Lower Cretaceous Lagerstätte of China (Yixian Formation), Middle Paleocene of France (Menat), Lower Eocene deposits of Germany (Geiseltal), Upper Eocene Baltic amber (Eastern Europe), Upper Eocene deposits of Florissant Formation (USA) and Miocene (Dominican amber). Tenebrionids of the following major lineages, including seven subfamilies, are currently known in the fossil record. These include the lagrioid branch (Lagriinae, Nilioninae), pimelioid branch (Pimeliinae), and tenebrioid branch (Alleculinae, Tenebrioninae, Diaperinae, Stenochiinae). The importance of the fossil record for evolutionary reconstructions and phylogenetic patterns is discussed. The oldest Jurassic and Early Cretaceous darkling beetles of the tenebrionoid branch consist of humid-adapted groups from the extant tribes Alleculini, Ctenopodiini (Alleculinae), and Alphitobiini (Tenebrioninae). Thus, paleontological evidence suggests that differentiation of the family started at least by the Middle Jurassic but does not indicate that xerophilic darkling beetles differentiated much earlier than mesophilic groups.
\end{abstract}

Keywords: fossils; Tenebrionidae lineages; fossil history; catalogue; evolutionary reconstructions

\section{Introduction}

Tenebrionidae is one of the largest beetle families, comprising nearly 20,000 extant species and 2300 genera in the World [1]. The monophyly of the family was justified by many authors in the 20th and 21st centuries [1] and was also recently supported after the analysis of eight gene markers, but at least two large subfamilies, Tenebrioniae and Diaperinae, seem to be paraphyletic or polyphyletic [2]. The systematics of tenebrionid beetles was modified by many authors. The currently accepted classification of the family is based on the analysis of multiple external and internal morphological structures [1,3-10] and includes 11 subfamilies [10-13] from lagrioid, pimelioid, and tenebrionoid branches [11]. Fossil Tenebrionidae have been used in evolutionary reconstructions [14,15]. The fossil record of darkling beetles is highly fragmented. Matthews et al. [1] briefly discussed the fossil record of Tenebrionidae, but since that time, important new data have been published. In the present work, the current data on extinct Tenebrionidae are summarized and analyzed. This includes a new catalogue of extinct darkling beetles, critical evaluation of fossil taxa, questions of systematics, and discussions of evolutionary scenarios and paleo-reconstructions. 


\section{Material and Methods}

Material from European and Asian museums as well as from private collections were used by the author in previous original descriptions of fossil taxa (see Table 2 and References for taxa, described by M.V. Nabozhenko and co-authors) with depositories listed in the original descriptions. In addition, a detailed analysis of the cited literature was included.

The following internet resources were used for catalogue numbers and the age of the fossils:

- Fossilworks: http://fossilworks.org/,

- International Commission on Stratigraphy: http://www.stratigraphy.org/,

- Catalogue of fossil Tenebrionidae: https://www.zin.ru/Animalia/Coleoptera/rus/teneb_ff.htm.

Authors and years of extant taxa were added according to recommendations of the International Code of Zoological Nomenclature in the redaction of 1999 (https://www.iczn.org/) and are not considered as cited literature to avoid excessive citation. References for all these taxa including authors and years of tribes and subfamilies can be found in many current catalogues.

\section{Brief History of the Study of Fossil Tenebrionidae}

Studies of fossil tenebrionids began with the papers by E.F. Germar [16] of the description of Tenebrio effossus from the Rott Formation (Upper Oligocene/Lower Miocene) of Germany. Brothers C. and L. Heyden described extinct Tenebrionidae from the same formation $[17,18]$, and O. Heer added many publications of fossil tenebrionids from the Miocene of Germany [19,20], Middle Cretaceous of Sakhalin, Russia [21] and Paleocene of Greenland [22]. The first fossil darkling beetles from North America (mostly Alleculinae) were described by S.H. Scudder [23,24] and Wickham [25-28] from the Eocene. R. Klebs [29] summarized data on beetles from Eocene Baltic amber with a list of genera and species (including Tenebrionidae). Later, materials of R. Klebs were lost, and the taxa mentioned in this work are impossible to verify.

The publications on fossil Tenebrionidae of the 19th century and beginning of the last century are characterized by rather short descriptions and unclear illustrations; thus, these described taxa need to be revised.

In the middle of the 20th century, the greatest contribution to the study of fossil tenebrionids was made by $\mathrm{H}$. Haupt [30] who described many genera and species from the Eocene of Germany (Geiseltal). Haupt used homologization of elytral venation for the identification of his taxa, most of which need further revision. L. Medvedev [31] qualitatively described and illustrated a comb-clawed beetle from the Mid/Late Jurassic of Karatau (Kazakhstan). Later, studies of fossil Tenebrionidae were resumed only at the end of the 20th century. S.G. Larson [32], and F. Hieke and E. Pietrzeniuk [33] greatly contributed to the knowledge on tenebrionids from Eocene Baltic amber. U. Spahr [34] published a detailed catalogue of all beetles from fossil amber and copal. Chinese authors [35,36] described several Alleculinae from the Miocene of China (Shanwang). Tenebrionidae from the Miocene Dominican amber were studied by Z. Kaszab and W. Schawaller [37] and later were summarized by Doyen and Poinar [38] who described many extinct darkling beetles from the subfamilies Lagriinae, Pimeliinae, Tenebrioninae, Diaperinae, and Stenochiinae.

The greatest progress in the study of extinct Tenebrionidae has been achieved in the last 10 years. A.G. Kirejtshuk et al. [39] published the very important work with a catalogue of fossil Tenebrionidae (more than 100 extinct taxa). This catalogue is regularly modified at the website "Beetles and coleopterologists" [40]. Our knowledge about Mesozoic darkling beetles has been expanded [41-43] with the publications of fossils Alleculinae and Tenebrioninae from the Yixian Formation of China. A significant contribution was made to the knowledge of Tenebrionidae from the Middle Paleocene deposits of Menat, France [44,45], European Eocene ambers (Baltic and Oise) [46-55], and the Oligocene/Miocene Dominican amber [56,57]. The taxonomic position of some genera, which were originally included to Tenebrionidae, was revised and corrected by Kirejtshuk et al. [58]. 


\section{Catalogue of Fossil Tenebrionidae}

Different catalogues were published for Mesozoic Tenebrionidae [59], darkling beetles from ambers [34], from Dominican amber [60], etc., but a complete catalogue of Tenebrionidae was compiled by Kirejtshuk et al. [39] and regularly updated on the website "Beetles (Coleoptera) and coleopterists" by Kirejtshuk and A.G. Ponomarenko [40].

A. Handlirsch [61] listed many doubtful taxa (such as Pseudotenebrio Weyenbergh, 1869, etc.), which can belong to any beetle family. These taxa are not included in the catalogue below.

The open catalogue of Kirejtshuk and Ponomarenko [40] requires updating with taxonomic changes. As a result, the present study is the most up to date catalogue of extinct Tenebrionidae. At present, 122 species of fossil Tenebrionidae in the time span of 201-11.6 Ma are known (Tables 1 and 2), some of which have been identified only to genus.

Table 1. Abbreviations of fossil deposits, used in the paper (made using data from the website Fossilworks: http://fossilworks.org/ and Catalogue of fossil Tenebrionidae: [39,40]; https://www.zin.ru/ Animalia/Coleoptera/rus/teneb_ff.htm).

\begin{tabular}{|c|c|}
\hline Fossil Deposits & Era(period) Age, Ma \\
\hline Early Jurassic, Rhaetian/Hettangian; Switzerland: Aargau, Schambelen & $\mathrm{Mz}(\mathrm{Ju}) 201.6-196.5$ \\
\hline Middle/Late Jurassic, Callovian/Oxfordian; Kazakhstan: Karatau & $\mathrm{Mz}(\mathrm{Ju})$ 164.7-155.7 \\
\hline Early Cretaceous, Aptian; China: Huangbanjigou, Chaomidian & $\mathrm{Mz}(\mathrm{Cr}) 125.5-122.5$ \\
\hline Early Cretaceous, Santonian; Russia: Sakhalin, Mgachi & $\mathrm{Mz}(\mathrm{Cr}) 85.8-84.9$ \\
\hline Early Paleocene, Danian; Argentina: El Sunchal & $\operatorname{Pg}(\mathrm{Pc}) 66-55.8$ \\
\hline $\begin{array}{l}\text { Middle Paleocene, Selandian; Denmark, Greenland: Aumarutigsat, } \\
\text { Haseninsel (Hareøen), }\end{array}$ & $\operatorname{Pg}(\operatorname{Pc}) 61.7-58.7$ \\
\hline Middle/Late Paleocene, Selandian/Thanetian; France: Menat & $\operatorname{Pg}(\mathrm{Pc}) 61-56$ \\
\hline Earliest Eocene, Oise amber, Ypresian; France: Le Quesnoy & $\operatorname{Pg}($ Eo) $55.8-48.6$ \\
\hline Early Eocene, Ypresian; Canada: Whipsaw Creek & $\operatorname{Pg}($ Eo $) 55.8-40.4$ \\
\hline Middle Eocene, Lutetian; Germany: Messel Pit & $\operatorname{Pg}($ Eo-Mess $)$ 48.6-40.4 \\
\hline Middle Eocene, Lutetian; Germany: Geiseltal Halle & $\operatorname{Pg}($ Eo-Geis $) 48.6-40.4$ \\
\hline Middle Eocene, Lutetian; United Kingdom: Bournemouth & $\mathrm{Pg}$ (Eo-Bour) $48.6-40.4$ \\
\hline Late Eocene, Baltic Amber, Priabonian; coasts of the Baltic Sea & $\operatorname{Pg}($ Eo-BA $) 37.2-33.9$ \\
\hline $\begin{array}{c}\text { Latest Eocene, Priabonian; USA, Colorado: Florissant, Twin Creek, Front } \\
\text { Range near Pike's Peak }\end{array}$ & Pg(Eo-Flor) 37.2-33.9 \\
\hline $\begin{array}{c}\text { Early Oligocene, Rupelian; France: Alsace, Haut-Rhine, } 5 \text { km SW } \\
\text { Mulhouse, Brunstatt }\end{array}$ & $\operatorname{Pg}(\mathrm{Og}) 33.9-28.4$ \\
\hline Late Oligocene/early Miocene, Chattian/Aquitanian; Germany: Rott & $\mathrm{Ng}(\mathrm{Mi}) 28.4-23$ \\
\hline Early Miocene, Aquitanian; Switzerland: Lausanne, Molasse & $\mathrm{Ng}(\mathrm{Mi})$ 23-20.4 \\
\hline $\begin{array}{c}\text { Early Miocene, Mexican amber, Aquitanian/Burdigalian; Mexico: Simojovel } \\
\text { area, Chiapas }\end{array}$ & $\mathrm{Ng}(\mathrm{Mi}) 23-16$ \\
\hline Early Miocene, Burdigalian; China: Linqu County, Shanwang & $\mathrm{Ng}$ (Mi-Shan) 20.4-16 \\
\hline Early Miocene, Burdigalian; Greece: Kumi, Euboea & $\mathrm{Ng}$ (Mi-Kumi) 20.4-16 \\
\hline Early Miocene, Dominican amber, Burdigalian; Dominican Republic & $\mathrm{Ng}(\mathrm{Mi}-\mathrm{Dom})$ 20.4-13.7 \\
\hline Middle Miocene, Langhian/Serravallian; Germany: Lower Saxony, Salzhausen & $\mathrm{Ng}(\mathrm{Mi}) 16.0-11.6$ \\
\hline Middle Miocene, Serravallian; Germany: Baden-Württemberg, Oeningen & $\mathrm{Ng}(\mathrm{Mi}) 12.7-11.6$ \\
\hline
\end{tabular}


Table 2. Catalogue of extinct darkling beetles (excluding Quartenary), based on the checklist of fossil Tenebrionidae by Kirejtshuk et al. [39], with additions and corrections; †-extinct genera.

\begin{tabular}{|c|c|c|c|}
\hline No. & Taxon & Age and Site of Finding & Sources \\
\hline \multicolumn{4}{|c|}{ Subfamily Lagriinae } \\
\hline \multicolumn{4}{|c|}{ Tribe Lagriini Latreille, 1825} \\
\hline 1 & Lagria sp. & $\operatorname{Pg}($ Eo-BA) 37.2-33.9 & {$[29,32,39]$} \\
\hline 2 & Statira sp. & $\mathrm{Pg}($ Eo-BA) 37.2-33.9 & {$[29,32,39]$} \\
\hline 3 & Statira baltica Telnov, Bukejs et Merkl, 2019 & $\operatorname{Pg}($ Eo-BA $) 37.2-33.9$ & [55] \\
\hline 4 & Statira dermoidea Doyen et Poinar, 1994 & $\mathrm{Ng}$ (Mi-Dom) 20.4-13.7 & {$[38,39,57]$} \\
\hline \multicolumn{4}{|c|}{ Tribe Laenini } \\
\hline 5 & Laena sp. & $\operatorname{Pg}($ Eo-BA) 37.2-33.9 & {$[29,32,34,39,62,63]$} \\
\hline \multicolumn{4}{|c|}{ Tribe Gonialaenini Nabozhenko, Telnov et Bukejs, 2019} \\
\hline 6 & $\begin{array}{l}\text { Gonialaenat groehni Nabozhenko, Telnov et } \\
\text { Bukejs, } 2019\end{array}$ & $\operatorname{Pg}($ Eo-BA) 37.2-33.9 & [51] \\
\hline \multicolumn{4}{|c|}{ Tribe Lupropini Lesne, 1926} \\
\hline 7 & Luprops sp. & $\operatorname{Pg}($ Eo-BA) 37.2-33.9 & [29] \\
\hline 8 & Lorelus angulatus Doyen et Poinar, 1994 & $\mathrm{Ng}$ (Mi-Dom) 20.4-13.7 & {$[38,39,57]$} \\
\hline 9 & Lorelus foraminosus Doyen et Poinar, 1994 & $\mathrm{Ng}$ (Mi-Dom) 20.4-13.7 & {$[38,39,57]$} \\
\hline 10 & Lorelus minutulus Doyen et Poinar, 1994 & $\mathrm{Ng}$ (Mi-Dom) 20.4-13.7 & {$[38,39,57]$} \\
\hline 11 & Lorelus wolcotti Doyen et Poinar, 1994 & Ng(Mi-Dom) 20.4-13.7 & {$[38,39,57]$} \\
\hline \multicolumn{4}{|c|}{ Tribe Belopini Reitter, 1917} \\
\hline 12 & $\begin{array}{l}\text { Yantaroxenost colydioides Nabozhenko, } \\
\text { Kirejtshuk et Merkl, } 2016\end{array}$ & $\operatorname{Pg}($ Eo-BA $) 37.2-33.9$ & {$[50]$} \\
\hline \multicolumn{4}{|c|}{ Subfamily Pimeliinae } \\
\hline \multicolumn{4}{|c|}{ Tribe Asidini Fleming, 1821} \\
\hline 13 & $\begin{array}{c}\text { Asida (Planasida) groehni F. Soldati et } \\
\text { Nabozhenko (2017 }\end{array}$ & $\operatorname{Pg}($ Eo-BA) 37.2-33.9 & [53] \\
\hline 14 & $\begin{array}{c}\text { Pelecyphorus (Stenosides) primus (Wickham, } \\
\text { 1910) (Ologlyptus), transferred to } \\
\text { Pelecyphorus by F. Soldati \& } \\
\text { Nabozhenko (2017) }\end{array}$ & $\operatorname{Pg}$ (Eo-Flor) 37.2-33.9 & {$[26,39,53]$} \\
\hline \multicolumn{4}{|c|}{ Tribe Stenosini Schaum, 1859} \\
\hline 15 & Miostenosist lacordairei Wickham, 1913 & $\operatorname{Pg}$ (Eo-Flor) 37.2-33.9 & {$[27,39]$} \\
\hline \multicolumn{4}{|c|}{ Tribe Edrotini Lacordaire, 1859} \\
\hline 16 & Trientoma hascens Doyen et Poinar, 1994 & $\mathrm{Ng}$ (Mi-Dom) 20.4-13.7 & {$[38,39,57]$} \\
\hline \multicolumn{4}{|c|}{ Subfamily Alleculinae } \\
\hline \multicolumn{4}{|c|}{ Tribe Alleculini Laporte, 1840} \\
\hline \multicolumn{4}{|c|}{ Subtribe Alleculina Laporte, 1840} \\
\hline 17 & Jurallecula† grossa L. Medvedev, 1969 & $\mathrm{Mz}(\mathrm{Ju})$ 164.7-155.7 & {$[31,39,59,64]$} \\
\hline 18 & Allecula austriaca Zhang, 1989 & $\mathrm{Ng}$ (Mi-Shan) 20.4-16 & {$[36,39]$} \\
\hline 19 & Allecula dominula (Heer, 1847) (Cistela) & $\mathrm{Ng}(\mathrm{Mi})$ 12.7-11.6 & {$[19,39,65]$} \\
\hline 20 & Allecula sp. & $\operatorname{Pg}($ Eo-BA $) 37.2-33.9$ & {$[29,32]$} \\
\hline 21 & Hymenorus haydeni Wickham, 1914 & $\operatorname{Pg}$ (Eo-Flor) 37.2-33.9 & {$[28,39]$} \\
\hline 22 & Hymenorus chiapasensis Campbell, 1963 & $\mathrm{Ng}(\mathrm{Mi}) 23-16$ & {$[39,66]$} \\
\hline 23 & Hymenorus oculatus Doyen et Poinar, 1994 & $\mathrm{Ng}$ (Mi-Dom) 20.4-13.7 & {$[38,39,57]$} \\
\hline 24 & Hymenalia sp. & $\operatorname{Pg}($ Eo-BA) $37.2-33.9$ & {$[29,32,39]$} \\
\hline 25 & Pseudocistela gracilis Förster, 1891 & $\mathrm{Pg}(\mathrm{Og}) 33.9-28.4$ & {$[27,39,65]$} \\
\hline 26 & Parahymenorus sp. & $\mathrm{Ng}(\mathrm{Mi}-\mathrm{Dom})$ 20.4-13.7 & {$[38,39]$} \\
\hline 27 & Lobopoda annosa Doyen et Poinar, 1994 & $\mathrm{Ng}$ (Mi-Dom) 20.4-13.7 & {$[38,39,57]$} \\
\hline 28 & Lobopoda sp. & $\mathrm{Ng}$ (Mi-Dom) 20.4-13.7 & {$[38,39]$} \\
\hline
\end{tabular}


Table 2. Cont.

\begin{tabular}{|c|c|c|c|}
\hline No. & Taxon & Age and Site of Finding & Sources \\
\hline \multicolumn{4}{|c|}{ Subtribe Mycetocharina Gistel, 1848} \\
\hline 29 & Mycetochara sp. & $\operatorname{Pg}($ Eo-BA $) 37.2-33.9$ & {$[29,32,39]$} \\
\hline 30 & Mycetocharoidest baumeisteri Schaufuss, 1888 & $\operatorname{Pg}($ Eo-BA) $37.2-33.9$ & {$[39,65,67,68]$} \\
\hline \multicolumn{4}{|c|}{ Subtribe Gonoderina Seidlitz, 1896} \\
\hline 31 & Gonodera antiqua (Wickham, 1913) (Cistela) & $\operatorname{Pg}($ Eo-Flor) 37.2-33.9 & {$[27,39]$} \\
\hline 32 & Gonodera vulcanica (Wickham, 1914) (Cistela) & $\operatorname{Pg}$ (Eo-Flor) 37.2-33.9 & {$[27,39]$} \\
\hline 33 & $\begin{array}{c}\text { Gonodera baygushevae Nabozhenko et I. } \\
\text { Chigray, } 2018\end{array}$ & $\operatorname{Pg}($ Eo-BA) 37.2-33.9 & [54] \\
\hline 34 & $\begin{array}{l}\text { Gonodera sp. (Cistela); } \\
\text { transferred to Gonodera by Spahr (1981) }\end{array}$ & $\operatorname{Pg}($ Eo-BA) 37.2-33.9 & {$[29,32,34,39,69]$} \\
\hline 35 & $\begin{array}{l}\text { Isomira (Mucheimira) avula Seidlitz, } 1896 \\
\text { (originally in the subgenus Asiomira; } \\
\text { transferred by Nabozhenko et al. 2019) }\end{array}$ & $\operatorname{Pg}($ Eo-BA $) 37.2-33.9$ & {$[39,52,65]$} \\
\hline 36 & $\begin{array}{l}\text { Isomira (Isomira) hoffeinsorum Nabozhenko } \\
\text { in Nabozhenko, I. Chigray et Bukejs, } 2019\end{array}$ & $\operatorname{Pg}($ Eo-BA) 37.2-33.9 & [52] \\
\hline 37 & Isomira sp. aff. hoffeinsorum & $\operatorname{Pg}($ Eo-BA $) 37.2-33.9$ & {$[52]$} \\
\hline 38 & $\begin{array}{l}\text { Isomira (subgenus incertus) florissantensis } \\
\text { Wickham, } 1914\end{array}$ & $\operatorname{Pg}$ (Eo-Flor) 37.2-33.9 & {$[28,39]$} \\
\hline 39 & Isomira (subgenus incertus) sp. & $\operatorname{Pg}($ Eo-BA $) 37.2-33.9$ & {$[29,32,39]$} \\
\hline 40 & Capnochroa senilis Wickham, 1914 & $\operatorname{Pg}$ (Eo-Flor) 37.2-33.9 & {$[28,39]$} \\
\hline \multicolumn{4}{|c|}{ Tribe Cteniopodini Solier, 1835} \\
\hline 41 & $\begin{array}{l}\text { Platycteniopust diversoculatus Chang, } \\
\text { Nabozhenko, } \mathrm{Pu}, \mathrm{Xu} \text {, Jia et } \mathrm{Li}, 2016\end{array}$ & $\mathrm{Mz}(\mathrm{Cr})$ 125.5-122.5 & {$[43,59,64]$} \\
\hline 42 & $\begin{array}{l}\text { Calcarocistelat kirejtshuki Nabozhenko in } \\
\text { Nabozhenko, Chang, Xu, Pu et Jia, } 2015\end{array}$ & $\mathrm{Mz}(\mathrm{Cr})$ 125.5-122.5 & {$[42,59]$} \\
\hline 43 & Cteniopus sp. & $\operatorname{Pg}($ Eo-BA) 37.2-33.9 & {$[29,32,39]$} \\
\hline 44 & Cteniopinus sp. & $\mathrm{Pg}($ Eo-BA) 37.2-33.9 & {$[33,39]$} \\
\hline 45 & Sinocistelat gymnelytra Zhang, 1989 & $\mathrm{Ng}$ (Mi-Shan) 20.4-16 & {$[36,39]$} \\
\hline 46 & Sinocistelat silpha Zhang, 1989 & $\mathrm{Ng}$ (Mi-Shan) 20.4-16 & {$[36,39]$} \\
\hline \multicolumn{4}{|c|}{ Subfamily Tenebrioninae } \\
\hline \multicolumn{4}{|c|}{ Tribe Palorini } \\
\hline 47 & Palorus sp. & $\operatorname{Pg}($ Eo-BA) 37.2-33.9 & {$[29,32,34,39,47,48,62,63]$} \\
\hline 48 & $\begin{array}{c}\text { Palorus platycotyloides Alekseev et } \\
\text { Nabozhenko, } 2017\end{array}$ & $\operatorname{Pg}($ Eo-BA $) 37.2-33.9$ & [48] \\
\hline 49 & $\begin{array}{c}\text { Vabolet triplehorni Alekseev et } \\
\text { Nabozhenko, } 2015\end{array}$ & $\operatorname{Pg}($ Eo-BA $) 37.2-33.9$ & {$[47,48]$} \\
\hline
\end{tabular}

Tribe Toxicini

\begin{tabular}{|c|c|c|c|}
\hline \multicolumn{4}{|c|}{ Subtribe Eudysantina } \\
\hline 50 & Wattius reflexus Doyen et Poinar, 1994 & $\mathrm{Ng}(\mathrm{Mi}-\mathrm{Dom})$ 20.4-13.7 & {$[38,39,57]$} \\
\hline \multicolumn{4}{|c|}{ Tribe Bolitophagini } \\
\hline 51 & $\begin{array}{c}\text { "Bolitophagus" vetustus Heyden et Heyden, } \\
1866\end{array}$ & $\mathrm{Ng}(\mathrm{Mi})$ 28.4-23 & {$[18,39,70,71]$} \\
\hline 52 & Bolitophagus sp. & $\operatorname{Pg}($ Eo-BA) 37.2-33.9 & {$[29,32,34,39,61,69-75]$} \\
\hline 53 & $\begin{array}{c}\text { Rhipidandrus quadripapillatus Doyen et } \\
\text { Poinar, } 1994\end{array}$ & $\mathrm{Ng}(\mathrm{Mi}-\mathrm{Dom})$ 20.4-13.7 & {$[38,39,57]$} \\
\hline 54 & Proteleatest centralis Wickham, 1914 & $\operatorname{Pg}$ (Eo-Flor) 37.2-33.9 & $\begin{array}{l}\text { [28,39] (as Protelerates in } \\
\text { the tribe Blaptini)] }\end{array}$ \\
\hline
\end{tabular}


Table 2. Cont.

\begin{tabular}{|c|c|c|c|}
\hline No. & Taxon & Age and Site of Finding & Sources \\
\hline \multicolumn{4}{|c|}{ Tribe Tenebrionini } \\
\hline 55 & Tenebrio primigenius Scudder, 1879 & $\operatorname{Pg}($ Eo) $55.8-40.4$ & {$[23,70,71,76]$} \\
\hline 56 & Tenebrio effossus Germar, 1837 & $\mathrm{Ng}$ (Mi) 28.4-23 & {$[16,39,70-72]$} \\
\hline 57 & Tenebrio senex Heyden, 1859 & $\mathrm{Ng}(\mathrm{Mi}) 28.4-23$ & {$[17,39,70,71]$} \\
\hline \multicolumn{4}{|c|}{ Tribe Alphitobiini } \\
\hline 58 & $\begin{array}{l}\text { Alphitopsist initialis Kirejtshuk, } \\
\text { Nabozhenko et Nel, } 2011\end{array}$ & & {$[41,59,64]$} \\
\hline \multicolumn{4}{|c|}{ Tribe Amarygmini } \\
\hline 59 & Meracantha lacustris Wickham, 1909 & $\operatorname{Pg}$ (Eo-Flor) 37.2-33.9 & {$[28,39]$} \\
\hline 60 & Cymatothes dominicus Doyen et Poinar, 1994 & $\operatorname{Pg}$ (Eo-Flor) 37.2-33.9 & {$[38,39,57]$} \\
\hline \multicolumn{4}{|c|}{ Tribe Helopini } \\
\hline 61 & $\begin{array}{c}\text { Cryptohelopst menaticus Nabozhenko et } \\
\text { Kirejtshuk, } 2014\end{array}$ & $\operatorname{Pg}\left(\mathrm{Pc}_{\mathrm{c}}\right) 61-56$ & {$[44,49,52]$} \\
\hline 62 & $\begin{array}{c}\text { Stenohelops (Stenolassus) klebsi (Nabozhenko, } \\
\text { Perkovsky et Chernei, 2016) } \\
\text { (originally as Nalassus, was transferred to } \\
\text { Stenohelops by Nabozhenko et al. (2019)) }\end{array}$ & $\operatorname{Pg}($ Eo-BA) 37.2-33.9 & {$[49,52]$} \\
\hline 63 & Helops meissneri Heer, 1847 & $(\mathrm{Ng}(\mathrm{Mi})$ 12.7-11.6 & {$[19,39,72,73]$} \\
\hline 64 & "Helops" sp. (genus incerta sedis) & $\operatorname{Pg}($ Eo-BA $) 37.2-33.9$ & {$[29,32,34,39,49,62,63]$} \\
\hline \multicolumn{4}{|c|}{ Tribe Triboliini } \\
\hline 65 & Tribolium sp. & $\operatorname{Pg}($ Eo-BA) 37.2-33.9 & {$[29,32,34,39,62,63]$} \\
\hline 66 & Hypodena marginalis Doyen et Poinar, 1994 & $\mathrm{Ng}$ (Mi-Dom) 20.4-13.7 & {$[38,39,57]$} \\
\hline \multicolumn{4}{|c|}{ Tribe Ulomini } \\
\hline 67 & Uloma sp. & $\operatorname{Pg}($ Eo-BA) 37.2-33.9 & {$[29,32,34,39,62,63]$} \\
\hline 68 & Uloma avia C. Heyden, 1862 & $\mathrm{Ng}(\mathrm{Mi}) 28.4-23$ & {$[70,71,77]$} \\
\hline \multicolumn{4}{|c|}{ Tribe Pedinini } \\
\hline \multicolumn{4}{|c|}{ Subtribe Leichenina } \\
\hline 69 & Leichenum sp. & $\operatorname{Pg}($ Eo-BA) 37.2-33.9 & {$[29,32,34,39,62,63]$} \\
\hline \multicolumn{4}{|c|}{ Tribe Opatrini } \\
\hline \multicolumn{4}{|c|}{ Subtribe Opatrina } \\
\hline 70 & Ephalus adumbratus Scudder, 1900 & $\operatorname{Pg}$ (Eo-Flor) 37.2-33.9 & {$[24,39,45]$} \\
\hline 71 & 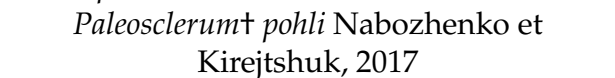 & $\operatorname{Pg}(\mathrm{Pc}) 61-56$ & [45] \\
\hline 72 & Ulus minutus Wickham, 1914 & $\operatorname{Pg}$ (Eo-Flor) 37.2-33.9 & {$[28,39,45]$} \\
\hline 73 & $\begin{array}{c}\text { Gonocephalum pristinum (Heyden et } \\
\text { Heyden, 1866) }\end{array}$ & $\mathrm{Ng}(\mathrm{Mi}) 28.4-23$ & $\begin{array}{c}{[18,39],[70] \text { (as Opatrum) }} \\
{[71] \text { (as Opatrum) }}\end{array}$ \\
\hline \multicolumn{4}{|c|}{ Subtribe Neopachypterina } \\
\hline 74 & Eupachypterust eocenicus & $\operatorname{Pg}($ Eo) 55.8-48.6 & {$[45,46]$} \\
\hline \multicolumn{4}{|c|}{ Subfamily Diaperinae } \\
\hline \multicolumn{4}{|c|}{ Tribe Diaperini } \\
\hline 75 & Ceropria (?) messelense Hornschemeyer, 1994 & $\operatorname{Pg}$ (Eo-Mess) 48.6-40.4 & {$[39,78]$} \\
\hline 76 & Platydema bethunei Wickham, 1913 & $\mathrm{Pg}($ Eo-Flor $) 37.2-33.9$ & {$[27,39]$} \\
\hline 77 & Platydema antiquorum Wickham, 1913 & Pg(Eo-Flor) 37.2-33.9 & {$[27,39]$} \\
\hline 78 & Platydema geinitzi Heyden et Heyden, 1866 & $\mathrm{Ng}(\mathrm{Mi}) 28.4-23$ & {$[18,39,70,71]$} \\
\hline
\end{tabular}


Table 2. Cont.

\begin{tabular}{|c|c|c|c|}
\hline No. & Taxon & Age and Site of Finding & Sources \\
\hline 79 & $\begin{array}{c}\text { Pentaphyllus cioides Kirejtshuk, Merkl et } \\
\text { Kernegger, } 2008\end{array}$ & $\operatorname{Pg}($ Eo-BA $) 37.2-33.9$ & {$[39]$} \\
\hline 80 & Liodema phalacroides Doyen et Poinar, 1994 & $\mathrm{Ng}$ (Mi-Dom) 20.4-13.7 & {$[38,39,57]$} \\
\hline 81 & Neomida senicula Doyen et Poinar, 1994 & $\mathrm{Ng}$ (Mi-Dom) 20.4-13.7 & {$[38,39,57]$} \\
\hline \multicolumn{4}{|c|}{ Tribe Scaphidemini } \\
\hline 82 & New fossil genust and a new species & $\operatorname{Pg}(\mathrm{Pc}) 61-56$ & $\begin{array}{c}\text { (Nabozhenko, Kirejtshuk, } \\
\text { in litt) }\end{array}$ \\
\hline \multicolumn{4}{|c|}{ Tribe Hypophlaeini } \\
\hline 83 & Corticeus tertarius Vitali, 2007 & $\mathrm{Ng}$ (Mi-Dom) 20.4-13.7 & {$[56]$} \\
\hline 84 & “Hypophloeus" sp. (Corticeus) & $\operatorname{Pg}($ Eo-BA) 37.2-33.9 & {$[34,79]$} \\
\hline \multicolumn{4}{|c|}{ Tribe Gnathidiini } \\
\hline \multicolumn{4}{|c|}{ Subtribe Anopidiina } \\
\hline 85 & Tyrtaeus azureus Doyen et Poinar, 1994 & $\mathrm{Ng}$ (Mi-Dom) 20.4-13.7 & {$[38,39,57]$} \\
\hline 86 & Tyrtaeus elongatus Doyen et Poinar, 1994 & $\mathrm{Ng}$ (Mi-Dom) 20.4-13.7 & {$[38,39,57]$} \\
\hline 87 & $\begin{array}{c}\text { Tyrtaeus flavoantennatus Doyen et } \\
\text { Poinar, } 1994\end{array}$ & $\mathrm{Ng}$ (Mi-Dom) 20.4-13.7 & {$[38,39,57]$} \\
\hline 88 & Tyrtaeus thoracicus Doyen et Poinar, 1994 & $\mathrm{Ng}$ (Mi-Dom) 20.4-13.7 & {$[38,39,57]$} \\
\hline 89 & Tyrtaeus cupreorutilans Vitali, 2008 & $\mathrm{Ng}(\mathrm{Mi}-\mathrm{Dom})$ 20.4-13.7 & {$[57]$} \\
\hline
\end{tabular}

\section{Subfamily Stenochiinae}

Pseudohelopst groenlandicus Haupt, 1950

(nom nov. by Haupt (1950) = Helops molassicus Heer, 1883 nec Helops molassicus Heyden, 1865)

Pyrochalcaspist geiseltalensis Haupt, 1950 Eodromust agilis (Meunier, 1915) (= aeneocupreus Pongrácz, 1935) Eodromust helopoides Haupt, 1950 Eodromust parous Haupt, 1956

Eodromust punctatostriatus Haupt, 1950 Eodromus† punctatosulcatus Pongrácz, 1935 Caryosomat rugosum Haupt, 1950

Parakeleusticust postumus Haupt, 1950 Mimohelopst venosus Haupt, 1950 Anthracohelopst gigas Haupt, 1950 Anthracohelopst minutus Haupt, 1950 Anthcarohelopst molassicus (Heyden, 1865)

102 Transferred from Helops to Anthracohelops Haupt, 1950 by Haupt [30]

Anthcarohelopst wetteravicus (Heyden et

$103 \quad$ Heyden, 1865)

Transferred from Helops to Anthracohelops by Haupt [30]

Nesocyrtosoma antiquus (Kaszab et

104 Schawaller, 1984) (originally described is Hesiodobates; transferred to Nesocyrtosoma by Doyen and Poinar [38]) Nesocyrtosoma antiquus Doyen et Poinar, 1994

Nesocyrtosoma celadonum Doyen et
$\operatorname{Pg}\left(\mathrm{Pc}_{\mathrm{c}}\right)$ 61.7-58.7

$[22,30,39,70,71]$

Pg(Eo-Geis) 48.6-40.4

$[30,39]$

$\mathrm{Pg}$ (Eo-Geis) 48.6-40.4

$\mathrm{Pg}$ (Eo-Geis) 48.6-40.4

$\mathrm{Pg}$ (Eo-Geis) 48.6-40.4

$\mathrm{Pg}$ (Eo-Geis) 48.6-40.4

Pg(Eo-Geis) 48.6-40.4

Pg(Eo-Geis) 48.6-40.4

$\mathrm{Pg}$ (Eo-Geis) 48.6-40.4

Pg(Eo-Geis) 48.6-40.4

$\mathrm{Pg}$ (Eo-Geis) 48.6-40.4

Pg(Eo-Geis) 48.6-40.4

$\mathrm{Ng}$ (Mi) 23-20.4

$[30,39,80]$

$[30,39]$

$[30,39]$

[30,39]

$[30,39,81]$

$[30,39]$

$[30,39]$

$[30,39]$

$[30,39]$

$[30,39]$

$[22,30,39,70,71]$

$\mathrm{Ng}$ (Mi) 16.0-11.6

$[22,30,39,70,71,75,82]$

Ng(Mi-Dom) 20.4-13.7

$[38,39,57]$

Ng(Mi-Dom) 20.4-13.7

$[38,39,57]$ Poinar, 1994 
Table 2. Cont.

\begin{tabular}{|c|c|c|c|}
\hline No. & Taxon & Age and Site of Finding & Sources \\
\hline 107 & $\begin{array}{c}\text { Nesocyrtosoma hadratum Doyen et } \\
\text { Poinar, } 1994\end{array}$ & $\mathrm{Ng}(\mathrm{Mi}-\mathrm{Dom})$ 20.4-13.7 & {$[38,39,57]$} \\
\hline 108 & $\begin{array}{l}\text { Nesocyrtosoma impensum Doyen et } \\
\text { Poinar, } 1994\end{array}$ & $\mathrm{Ng}$ (Mi-Dom) 20.4-13.7 & {$[38,39,57]$} \\
\hline 109 & $\begin{array}{c}\text { Nesocyrtosoma phthanatum Doyen et } \\
\text { Poinar, } 1994\end{array}$ & $\mathrm{Ng}$ (Mi-Dom) 20.4-13.7 & {$[38,39,57]$} \\
\hline \multicolumn{4}{|c|}{ Tenebrionidae, family incertae sedis } \\
\hline 110 & Parapiophorust nitidus Haupt, 1950 & $\operatorname{Pg}($ Eo-Geis) 48.6-40.4 & {$[30,39]$} \\
\hline 111 & Eohelaeust perpunctatus Haupt, 1950 & $\operatorname{Pg}$ (Eo-Geis) 48.6-40.4 & {$[30,39]$} \\
\hline 112 & Eohelaeust sublaevis Haupt, 1950 & $\operatorname{Pg}$ (Eo-Geis) $48.6-40.4$ & {$[30,39]$} \\
\hline 113 & Eoallognosist limbellus Haupt, 1950 & $\operatorname{Pg}$ (Eo-Geis) 48.6-40.4 & {$[30,39]$} \\
\hline 114 & Rhinohelaeitest longipes Haupt, 1950 & $\operatorname{Pg}$ (Eo-Geis) $48.6-40.4$ & {$[30,39]$} \\
\hline 115 & Rhinohelaeitest punctatulus Haupt, 1950 & $\operatorname{Pg}$ (Eo-Geis) 48.6-40.4 & {$[30,39]$} \\
\hline 116 & Rhinohelaeitest undulatus Haupt, 1950 & $\operatorname{Pg}$ (Eo-Geis) 48.6-40.4 & {$[30,39]$} \\
\hline 117 & Tenebrionitest alatus Cockerell, 1920 & $\operatorname{Pg}$ (Eo-Flor) 37.2-33.9 & {$[39,83]$} \\
\hline 118 & Tenebrionitest anglicus Cockerell, 1920 & $\mathrm{Pg}$ (Eo-Bour) 48.6-40.4 & {$[39,83]$} \\
\hline 119 & Tenebrionitest inclinans Cockerell, 1925 & $\operatorname{Pg}(\mathrm{Pc}) 66-55.8$ & {$[39,83]$} \\
\hline 120 & Protoplatycerat laticornis Wickham, 1914 & $\operatorname{Pg}($ Eo-Flor $) 37.2-33.9$ & {$[28,39]$} \\
\hline 121 & Tagenopsist brevicornis Heer, 1865 & $\mathrm{Ng}(\mathrm{Mi}) 12.7-11.6$ & {$[20,70,71,75]$} \\
\hline 122 & $\begin{array}{l}\text { Eocallidium }+ \text { rugulosum Haupt, 1950, } \\
\text { transferred from Cerambycidae to } \\
\text { Tenebrionidae by Vitali [84] }\end{array}$ & $\operatorname{Pg}$ (Eo-Geis) 48.6-40.4 & {$[30,85]$} \\
\hline \multicolumn{4}{|c|}{ Coleoptera, family incertae sedis } \\
\hline 1 & Cistelitest insignis Heer, 1865 & $\mathrm{Mz}(\mathrm{Ju})$ 201.6-196.5 & {$[20,59]$} \\
\hline 2 & Cistelitest sachalinensis Heer, 1878 & $\mathrm{Mz}(\mathrm{Cr}) 85.8-84.9$ & {$[22,39,59,65]$} \\
\hline 3 & Cistelitest minor Heer, 1883 & $\operatorname{Pg}(\mathrm{Pc}) 61.7-58.7$ & {$[22,39,65]$} \\
\hline 4 & Cistelitest punctulatus Heer, 1883 & $\operatorname{Pg}\left(\mathrm{Pc}_{\mathrm{c}}\right) 61.7-58.7$ & {$[22,39,65]$} \\
\hline 5 & $\begin{array}{l}\text { Cistelitest longipes (Hong, 1985) (Procarabus), } \\
\text { transferred to Cistelites by Zhang [36] }\end{array}$ & $\mathrm{Ng}$ (Mi-Shan) 20.4-16 & {$[35,36,39]$} \\
\hline 6 & Cistelitest spectabilis Heer, 1847 & $\mathrm{Ng}(\mathrm{Mi})$ 12.7-11.6 & {$[19,39,65]$} \\
\hline 7 & $\begin{array}{c}\text { "Helops" atticus Redtenbacher in } \\
\text { Unger, } 1867\end{array}$ & $\mathrm{Ng}(\mathrm{Mi}-\mathrm{Kumi})$ 20.4-16 & {$[39,44,84]$} \\
\hline
\end{tabular}

The following abbreviations (Table 1) are used for the various fossil deposits in Table 2, the figure, and the text below.

\section{The Fossil Record of Major Tenebrionid Lineages}

\subsection{Tenebrionoid Branch.}

\subsubsection{Subfamily Alleculinae}

The oldest known distinct representatives of Tenebrionoidea are from the Callovian/Oxfordian of the Middle/Late Jurassic, Wuhua jurassica (Wang et Zhang, 2011) [86] and Praemordella martynovi (Shchegoleva-Barovskaya, 1929) [87] and belong to the clade Mordellidae-Ripiphoridae of this superfamily [59]. Archaeoripiphorus nuwa (Hsiao et al., 2017) [88] from the same stage was originally described in Ripiphoridae but was later transferred to Tenebrionoidea familia incertae sedis [59]. Mordellid-ripiphorid beetles reach the largest proportion of the described taxa (32\%) within Mesozoic Tenebrionoidea. Darkling beetles reach 11\%, with the predominance of Alleculinae [59]. Such imbalances in the record seem to be a result of the fossilization: Ripiphoridae and Mordellidae are small beetles, common in Burmese amber, while much larger Mesozoic tenebrionids are known from Burmese amber by a single undescribed specimen; the majority of the Mesozoic tenebrionids 
were described from compression prints in a stone matrix. This is due to the different fossilization of bio-inclusions entering fossil resins and various types of compression in burials.

The oldest tenebrionid beetle Cistelites insignis (formally Alleculinae) from the Early Jurassic has an unclear position within Coleoptera, and the holotype of this species (print of single elytron) must be re-examined. The Middle/Late Jurassic Jurallecula grossa clearly belongs to the subfamily Alleculinae and, judging from its characters (preapical tarsomeres not bilobed), to the gonoderine branch of Alleculini [31]. Alleculinae are known by two described species from the Yixian Formation of the Lower Cretaceous [42,43], herewith Calcarocistela kirejtshuki, which belongs to gonoderine branch, and Platycteniopus diversoculatus has characters intermediate between those known in the alleculine and cteniopodine branches of the subfamily. All extant Cteniopodini associated with generative organs of Angiosperms and the age of Platycteniopus corresponds to the age of the early stages of the Angiosperm evolution. Probably, the origin of the tribe Cneniopodini should be dated to the Jurassic-Cretaceous border.

Many species of the formal genus Cistelites Heer, 1865, described from the Lower Jurassic of Switzerland (C. insignis), the Upper Cretaceous of Sakhalin (C. sachalinensis), the Lower Paleocene of Greenland (C. minor and C. punctulatus), the Middle Miocene of China (C. longipes) and the Upper Miocene of Germany (C. spectabilis) cannot be interpreted as possible close relatives, and this genus cannot be placed in the current classification due to its very sparse description. These taxa are not included in this review.

Numerous and diverse material on Alleculinae appears in the Cenozoic (Paleogene), especially in the Eocene Baltic and the Rovno amber, where mainly extant and one extinct (Mycetocharoides Schaufuss, 1888) genera are represented. The most diverse group among Baltic Alleculinae is the subtribe Gonoderina (tribe Alleculini). Two genera Isomira Mulsant, 1856 and Gonodera Mulsant, 1856 presented in the Recent fauna are registered in Baltic amber [52,54,65], herewith some extinct species of Isomira belong to the subgenera distributed in recent East Asia. This suggests that the most archaic representatives of this genus survived in the Palaearctic Asia and dispersed to the East Palaearctic, that is consistent with data on other families of beetles and plants [89,90]. The subtribe Alleculina, represented in Baltic amber by the genera Allecula Fabricius, 1801, Mycetochara Guérin-Méneville, 1827, and Hymenalia Mulsant, 1856, occur in the recent fauna and as well as the extinct genus Mycetocharoides, which only slightly differs from Mycetochara. The tribe Ctenipodini is known from Baltic amber by two extant genera, Cteniopus Solier, 1835, and Cteniopinus Seidlitz, 1896. The gonoderine taxa from the genera Gonodera and Capnochroa LeConte, 1862 [27,28], and the alleculine Hymenophorus Mulsant, 1851 [27], were described from the volcanic deposits of Florissant with a comparable age. It should be added that Doyen and Poinar [38] doubted the correctness of the Wickham's identifications. Only extant genera are known from the Neogene deposits [28], excluding the extinct genus Sinocistela Zhang, 1989, from the Miocene of China. Sinocistela clearly belongs to the tribe Cteniopodini because it has six exposed abdominal ventrites.

Based on the fossil record, the oldest tenebrionids are gonoderine comb-clawed beetles (tribe Alleculini, subtribe Gonoderina) with non-lamellar and non-bifurcated preapical tarsomeres. They are known from the Late Jurassic. However, taken into consideration their "modern" body, it can be assumed that this group probably originated earlier, perhaps in the Middle Jurassic.

Mesozoic gonoderine comb-clawed beetles are characterized by the morphological conservatism and slightly differ from the extant taxa of the subtribe Gonoderina (tribe Alleculini), with some particular adaptations, such as very long metatarsal spurs in Calcarocistela. Unlike Cteniopodini, many Alleculini feed on Cyanophita, Bryophita, or lichens growing on trunks of trees; only adults of some groups (for example, Isomira) switched to feeding on the generative organs of Dicotyledones, but their larvae develop in rotten wood, as do the larvae in most Alleculini [91,92].

The alleculine branch (subtribe Alleculina) appears in the fossil record only in the late Eocene, but that seems to be caused by a lack of material. Diverse taxa of this subtribe currently are widely 
distributed on all continents, and they most likely originated much earlier than indicated in the fossil record.

Separation of the alleculine and cteniopodine branches could have occurred at the Jurassic-Cretaceous border. Extant Cteniopodini feed on flowering plants: therefore, it is assumed that the appearance of the angiosperms promoted diversification of the subfamily.

\subsubsection{Subfamily Tenebrioninae}

Tenebrioninae is the largest and probably most diverse subfamily of darkling beetles in the Recent fauna. The oldest representative of this subfamily, Alphotopsis initialis, was found in the Lower Cretaceous Lagerstätte of Yixian, China [41]. This species, described from a well-preserved print, is very similar to extant taxa of the tribe Alphitobiini (in particular to Alphitobius Stephens, 1829) and has all characters typical for the subfamily, including intersegmental abdominal membranes, defensive glands, and open mesocoxal cavities with well-expressed trochantin. Only this particular species is known from the Mesozoic. Other tenebrionines appear in the fossil record with a long break only in the Middle Paleocene (the Thanetian in Menat, France). Taxa of Helopini and Opatrini are known from this deposit $[44,45]$. Representatives of these two tribes belong to extinct genera but have features of specialization as in the extant tenebrionids from these groups. For example, Cryptohelops menaticus is very similar to the extant genus Stenohelops sensu str., by having widened male protarsi, coarsely punctured prohypomera, cordiform pronotum, lacking wings, and epipleura not reaching the apex. Furthermore, the emargination on the inner side of the protibiae of Cryptohelops menaticus is characteristic also of some extant genera from the subtribe Helopina.

Paleosclerum pohli belongs to the specialized myrmecophilous group of the subtribe Sclerina, as some extant genera of the tribe Opatrini. One extinct opatrine genus, Eupachypterus eocenicus from the subtribe Neopachypterina is known from Lower Eocene Oise amber [46]. The extant taxa of this subtribe occur in the Indo-Malayan and Afrotropic regions, while others are distributed in transitional biogeographical areas of the Palaearctic.

All these findings (including taxa of Opatrini from distinct subtribes) indicate a much earlier Mesozoic diversification of various tribes of the subfamily Tenebrioninae.

The next Paleogene time period with diverse and multiple samples of Tenebrioninae is the late Eocene-early Oligocene, especially Baltic amber and Upper Eocene deposits of Florissant in the USA. Mainly extant genera from the tribes Bolithophagini, Pedinini, Triboliini, Ulomini, Helopini, Palorini are known in Baltic amber. Amber specimens listed by Klebs [29] are lost, and those taxa cannot be compared with extant ones. Helopini are represented by one abundant species Stenohelops klebsi [49]. This species is very similar to Nalassus spp. (subtribe Cylindrinotina) and was initially described in this genus. After the study of additional materials, it was transferred to the genus Stenohelops (subtribe Helopina) on the basis of the catomoid type of aedeagus [93,94], absence of grooves near the lower surface of eyes, double bead of abdominal ventrite 5, and widened male protarsi [52]. Palorini are represented in Baltic amber by two genera, the extinct Vabole Alekseev et Nabozhenko, 2015, and extant Palorus Mulsant, 1854. Eocene species of both taxa belong to the life form with flattened bodies, similar to those in the Gondvanian generic group Platycotylus-Australopalorus $[47,48]$.

Four taxa of the subfamily Tenebrioninae were described from the Florissant deposits: two species of Opatrini, one from Bolithophagini and one from Amarygmini [24,28]. Both fossil species of Opatrini, Ephalus adumbratus and Ulus minutus (subtribe Opatrina) belong to the extant xeromorphic psammophilous genera with species occurring in inner-continental and marine supralittoral landscapes. Proteleates centralis, described in the tribe Bolithophagini, is very similar to the extant Neotropic genus Eleates Casey, 1886 (this genus was erroneously listed as Proteleratus and included to the tribe Blaptini by Kirejtshuk et al. [39]). Heyden and Heyden [18] erroneously placed Bolitophagus vetustus in this genus on the basis of two thin horns on the head. This species should be transferred to another genus of Bolitophagini, because this head character is typical for the extant Eastern Palaearctic and Indo-Malayan genus Byrsax Pascoe, 1860; some Neotropic Megeleates Casey, 1895, also have horns on 
the head. Wickham described Meracantha lacustris in the tribe Amarygmini; the second known species (extant) of this genus is distributed in North America and feeds on arboreal lichens.

Within the Palaeogene Tenebrionidae are some taxa with unclear positions (including members of the genera Tenebrio Linnaeus, 1758, Bolitophagus Illiger, 1798, and Uloma Dejean, 1821), from the Lower Eocene deposits of Canada (Whipsaw Creek) [23] and the Upper Oligocene deposits of Rott in Germany [16-18], which were only briefly described and poorly illustrated. Only the recent genera occur in the Neogene. The most reliable information relates to taxa from the genera Wattius Kaszab, 1982 (Toxicini), Rhipidandrus LeConte, 1862 (Bolithophagini), Cymatothes Dejean, 1834 (Amarygmini), and Hypogena Dejean, 1834 (Triboliini), described from the Miocene Dominican amber [38]. The majority of mentioned genera are spread in the Neotropics and partly in the Nearctic regions, with the exception of Rhipidandrus, species of which are known from all tropical areas of the World.

Within the described Neogene darkling beetles, the Miocene Helopini are the most diverse, but the tribal position of these taxa is very doubtful. All these species were described in the genus Helops sensu lato, which in the 19th century contained the most current helopin genera and many unclear genera from different subfamilies of tenebrionid beetles. It is impossible to clarify the taxonomic position of these taxa without examining the type specimens. Comments on these species are given below:

[Helops] atticus Redtenbacher in Ungern, 1867 (Ng(Mi-Kumi) 20.4-16). This species was described on the basis of the print of the right elytron and compared with extant Entomogonus peyronis (Reiche, 1861) and Erionura gigantea (Kraatz, 1862). The high-quality image in the original description does not give any reason to clearly attribute this print to any subfamily of Tenebrionidae. As a result, this species is regarded as Coleoptera, family incertae sedis.

[Helops] meissneri Heer, 1847 (Tafel V, Figure 9) ( $\mathrm{Ng}(\mathrm{Mi}) 12.7-11.6)$. This print, as described in detail, can belong to Helops sensu str. Its most peculiar character is the distinct deflected lateral margin of elytra. Its head is very poorly preserved and cannot be used for diagnostics. O. Heer mentioned in the original description that its elytra are similar to some Carabus Linnaeus, 1758, but the clearly-expressed full elytral striae indicate the possible position of this species within the genus Helops. Unfortunately, the image in the original description is not informative.

\subsubsection{Subfamily Stenochiinae}

The oldest representative of the subfamily Stenochiinae is known from the early Paleocene of Greenland (Pg(Pc) 61.7-58.7): Pseudohelops groenlandicus (originally Helops molassicus Heer, 1883). Haupt [30] compared this genus and species with the Eocene species of Anthracohelops on the basis of a similarity in the metallic shine of its elytra but contraposed both genera in the structure of elytral striae. Other Stenochiinae are known from the Middle Eocene of Germany (Pg(Eo-Geis) 48.6-40.4), where they were hugely diverse [30]. Haupt described several taxa in 1950 [30]: Pyrochalcaspis (one species), Eodromus (five species), Caryosoma (one species), Paraceleusticus (one species), Anthracohelops (four species), Mimohelops (one species) and Pseudohelops (one species). He divided all these genera by the structure of pronotum and the elytral sculpture. The first two can be compared with the extant species of the Neotropic genus Hegemona Laporte, 1840 (Cnodalonini), which also have fusiform convex elytra with very deeply impressed strial furrows. The genus Eodromus was compared by Haupt with extant representatives of the Neotropic genus Camaria Lepeletier and Audinet-Serville, 1828. However, Eodromus distinctly differs from Camaria and allied Neotropic genera (Mylaris Pallas, 1781, Taphrosoma Kirsch, 1866, etc.) in the absence of humeral angles (while the mentioned extant genera have clear humeral angles and callosity indicating the ability to fly). Eodromus can be compared with recent Hegemona, which are also wingless and have very similar elytral sculpture. Another genus, Cariosoma Haupt, 1950, "close" (according to Haupt) to Eodromus, has strongly sculptured elytra with elongate tubercles, similar to those in the Indo-Malayan taxa of the tribe Cnodalonini (Morphostenophanes Pic, 1925, and allied genera). Parakeleusticus postumulus is very similar to the recent Hegemona resplendens Laporte, 1840, from Southern Mexico. The taxonomic position of other mentioned genera of the 
subfamily Stenochiinae remain unclear, although Haupt compared them with the recent Camaria (Cnodalonini).

Thus, in the early Eocene of Geiseltal (Pg(Eo-Geis)48.6-40.4) the thermophilic and humid adapted species of the subfamily Stenochiinae, similar to those from Recent Neotropic and Indo-Malayan taxa, were well represented. This, as in the case of the Coleoptera composition in the earliest Eocene amber Oise, could be just at the beginning of the transition from the climatic thermo-era to cryo-era, from the thermal maximum in the Paleocene-Eocene to the global trend of climate cooling in the Middle Eocene-late Oligocene [95].

Other fossil Stenochiinae, all from the extant genus Nesocyrtosoma Marcuzzi, 1976, are known only from Neogene Dominican amber [38].

\subsubsection{Subfamily Diaperinae}

Diaperinae are poorly represented in the fossil record. This feature probably relates to their secretive lifestyle in natural landscapes, such as inside tunnels of bark beetles (Hypophlaeini), in the litter of trees and shrubs (many Gnathidini), in tree mushrooms, and under the bark (Diaperini, Scaphidemini).

The oldest extinct genus of Diaperinae was found in the Paleocene of Menat ( $\mathrm{Pg}(\mathrm{Pc}) 61-56)$ and belongs to the tribe Scaphidemini (Nabozhenko \& Kirejtshuk, in litt.).

Ceropria messelense was described from the early Eocene of Germany (Pg(Eo-Mess)48.6-40.4), although this genus was determined by the author with doubts [80]. Extant representatives of this genus are widespread in the Indo-Malayan Region.

Some Diaperinae were listed from the late Eocene to early Oligocene: $\operatorname{Pg}(\mathrm{Eo}-\mathrm{BA}) 37.2-33.9$ and $\mathrm{Pg}$ (Eo-Flor) 37.2-33.9. All of them belong to extant genera of the tribe Diaperini: two species of Platydema Laporte and Brullé, 1831, from Florissant [27], and one species of Pentaphyllus Dejean, 1821, [39] from Baltic Amber. The recent representatives of the first genus are widely distributed in the Palaearctic, Nearctic, Indo-Malayan, Afrotropic, and Neotropic regions. Pentaphyllus occurs in the same biogeographical regions, except Neotropic.

Miocene Dominican amber is characterized by the slightly more diverse composition of diaperines. Only the species from the extant widely distributed groups were listed in this source: Hypophlaeini (Corticeus Piller and Mitterpacher, 1783, worldwide distribution), Gnathidini (Tyrtaeus Champion, 1913, Australia, Neotropic, Nearctic), Diaperini (Neomida Latreille, 1829, all biogeographical regions, except for Australia; Liodema Horn, 1870, Nearctic, Neotropic) [38,56,57].

\subsection{Pimelioid Branch}

Subfamily Pimeliinae

Taxa of pimeliine branches are poorly represented in the fossil record because they probably occurred, as did the Recent members of this tribe, mostly in arid biomes (deserts and semideserts), and they would rarely be deposited in tree resin or compression lacustine burials. However, even single records are of great interest because they can help to analyze the diversification of pimeliine tribes, as well as to reconstruct paleo landscapes.

In the paleontological record, only extant tribes of Pimeliinae are presented (Asidini and Stenosini). Fossil species of tribe Asidini were found in the deposits of Florissant (Pg(Eo-Flor) 37.2-33.9) (Pelecyphorus (Stenosides) primus) [27] and in Baltic amber (Asida (Planasida) groehni) [53]. Both species belong to extant subgenera and undoubtedly demonstrate the earlier (possibly, early Eocene or late Paleocene) diversification of these groups. The finding of fossil Asida groehni in Baltic amber permits a more critical look at various reconstructions of the Baltic amber forest, in which the presence of xerophytic landscapes was not assumed in previous interpretations, and also the taphonomic reasons and selectivity of the amber fauna were not always taken into account $[96,97]$. Meanwhile, the Palaearctic genera of this tribe are xeromorphic (closed mouthparts without membranous surfaces, 
developed subelytral cavity, etc.) and include species of Asida Latreille, 1802, and allied genera that inhabit dry landscapes in arid Mediterranean woodlands, steppes, and semideserts. At least arid woodlands undoubtedly existed in the late Eocene landscapes of the Paleo-Eurasia.

Another fossil representative of the subfamily Pimeliinae belongs to the tribe Stenosini, which includes the myrmecophilous species, sporadically occurring in the Recent New World and widespread in the Recent Old World, mainly in the Palaearctic and the dry subtropics of the Indo-Malayan Region. Miostenosis lacordairei, described from the Eocene Florissant deposits on the basis of well-preserved print [27], is externally similar to the Palaearctic Stenosis Herbst, 1799. A distinctive feature of Miostenosis Wickham, 1913 is large round eyes, not characteristic of Stenosini, which have narrow, partly, or completely divided eyes, sometimes oval dorsally (some Stenosis). The taxonomic position of this extinct species is still unclear.

A single Neogene fossil representative of the extant genus of the tribe Edrotini, Trientoma hascens, was described from Miocene Dominican amber [38]. The extant species of this genus are distributed in the West-Indies and often occur in coastal dry woodlands or dry subtropic forests.

\subsection{Lagrioid Branch}

\subsubsection{Subfamily Lagriinae}

The subfamily is first known in the fossil record in Cretaceous Burmese amber (yet undescribed species of the tribe Lagriini: Statirina from Burmese amber). After a long time gap in the fossil record the lagriine taxa appear in the Middle Paleogene (most diverse in Eocene Baltic amber), genera from which four tribes were listed: Laena Dejean, 1821 (Laenini), Gonialaena (Gonialaenini), Luprops Hope, 1833 (Lupropini), Lagria Fabricius, 1775, and Statira Lepeletier and Audinet-Serville, 1828 (Lagriini), and also extinct Yantaroxenos (Belopini) [39,50,51]. Two from six described genera (33\%) are extinct (Gonialaena, Yantaroxenos).

The genus Yantaroxenos is most similar to the Neotropic Rhypasma Pascoe, 1862, which indicates ancient connections of the Early and Middle Paleogene faunas of Coleoptera of different paleo continents [29,32]. Records of many taxa of the mainly tropic subfamily Stenochiinae in early Eocene deposits of Geiseltal (Pg(Eo-Geis) 48.6-40.4) [30] also support this assumption.

The separate tribe Gonialaenini was erected for the genus Gonialaena because it combines some characters of the tribes Laenini, Goniaderini, Lupropini, and Lagriini and, possibly, represents a Mesozoic relic that survived until the late Eocene [51].

In Neogene Dominican amber are the only known fossil species of Lorelus Sharp, 1876, and Statira [38]. The extant taxa of the first genus are widely distributed in the New World; however, extant species of Statira occur in the Indo-Malayan, Nearctic, and Neotropic regions.

\subsubsection{Subfamily Nilioninae}

These unusual darkling beetles were interpreted within the Lagrioid branch of Tenebrionidae [1]. All extant taxa of the subfamily are Neotropic. The only extinct species Nilio dominicanum was described from the Miocene Dominican amber [98]. The species was originally described as dominicana but should be corrected to dominicanum according to the neuter generic gender. The extant species of Nilioninae feed and develop on lichens $[1,99]$.

\section{The Fossil Record of Tenebrionidae in Evolutionary Reconstructions}

The conclusions regarding fossil Tenebrionidae are primarily assumptions based on incomplete material rather than postulates.

In the current evolutionary scenario using molecular dating and diversification analyses, Kergoat et al. [14] suggested that Tenebrionidae originated after the Triassic-Jurassic mass extinction, and diversification of the major branches of Tenebrionidae proceeded in the period of Pangaean and Gondwanan breakups. These authors established that arid-adapted darkling beetles (mostly 
Pimeliinae) diversified earlier (in the Middle-Late Jurassic), while the humid-adapted tenebrionids (Tenebrioninae, Diaperinae, Stenochiinae) diversified much later, in the early and late Cretaceous (Alleculinae).

Generally, the fossil record supports this view (Figure 1), but some discrepancies can be found. Based on the record of Middle/Late Jurassic Jurallecula grossa (Mz(Ju) 164.7-155.7), L. Medvedev [31] was the first who assumed (long before modern studies), that Tenebrionidae originated in the early Jurassic or slightly earlier. So, his estimated time of the origin of darkling beetles does not contradict Kergoat et al. [14]. Despite the lack of paleontological evidence, the presumably Jurassic diversification of the pimelioid branch as assumed by Matthews et al. [1] and Kergoat et al. [14] can be supported. It can also be assumed that the pimeliine tenebrionids during the Jurassic were diversified and produced main separated phyletic branches because, among all extant representatives of the largest subfamily Pimeliinae and the small Kuhitangiinae, mesophilic humid-adapted groups are absent.

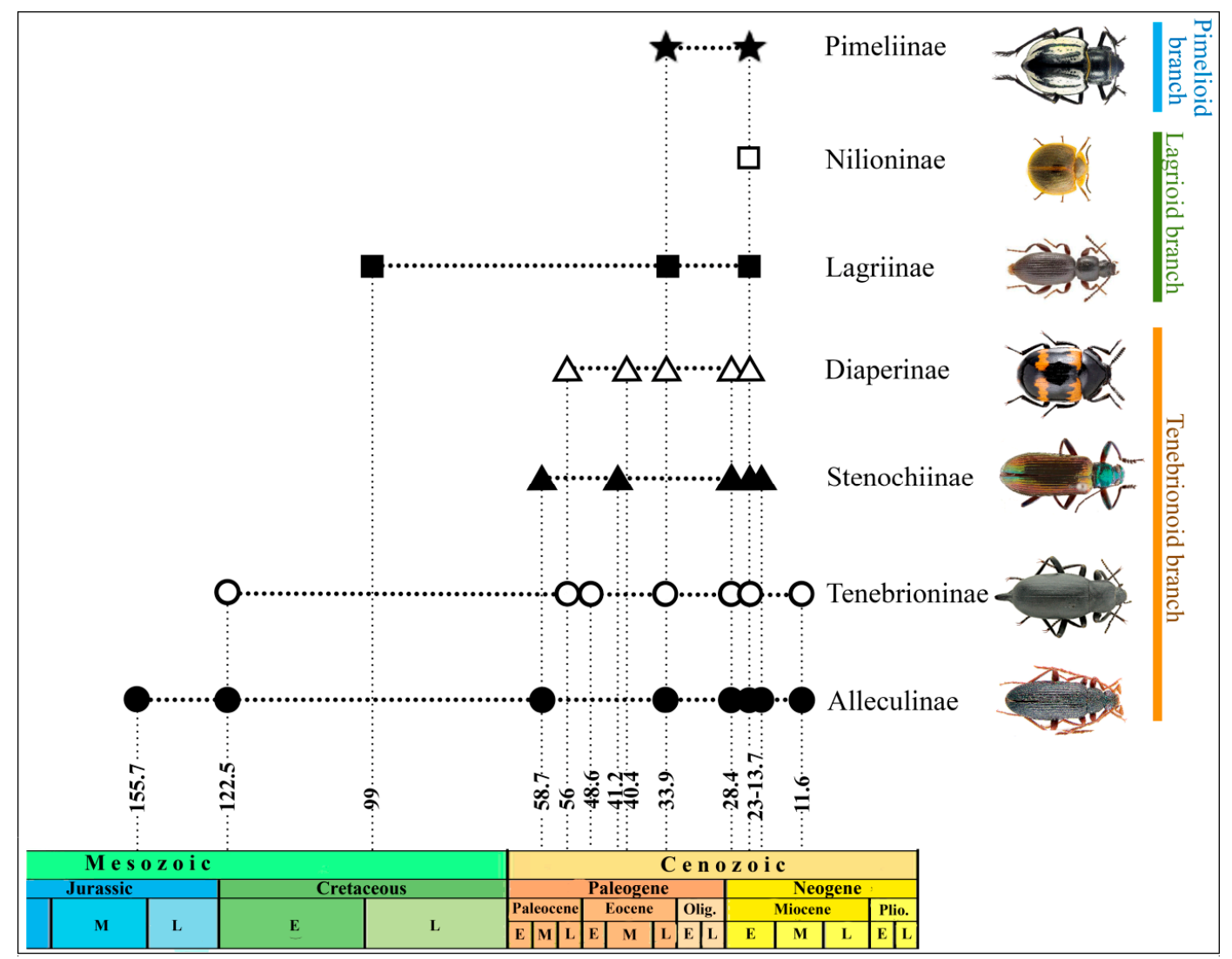

Figure 1. Tenebrionidae in the fossil records. Numbers show minimal age of fossils.

The oldest Jurassic and Jurassic-Cretaceous darkling beetles of the tenebrionine lineage belong to humid-adapted groups from the extant tribes Alleculini, Ctenopodiini (Alleculinae), and Alphitobiini (Tenebrioninae) (Figure 1). Thus, Paleontological evidence supports a hypothesis that the differentiation of the family started at least in the Middle Jurassic, regardless of whether the ancestral forms of Tenebrionidae were xerophilic or mesophilic (Figure 1). In this case, paleontological evidence contradicts the scenario suggested by Kergoat with coauthors [14].

A more or less distinct time interval can be established only for the origin of the tribe Cteniopodini. The oldest genus of this tribe, Platycteniopus $(\mathrm{Mz}(\mathrm{Cr})$ 125.5-122.5), combines both the features of gonoderine ancestors and the "new" cteniopodine characters, which are explained by the change of trophic specialization of all representatives of this tribe to feeding on generative organs of angiosperms. This is the only known case of the direct impact of early angiosperms on the evolution of darkling beetles. In this case, we support the opinion of Kergoat with co-authors [14] about the insignificant 
impact of angiosperms on the diversification of tenebrionids, contrary to Yu et al. [64], who indicated the origin of Tenebrionidae in the Cretaceous (near $120 \mathrm{Ma}$ ) and an important role of angiosperms in their evolution.

The main contradiction is a discrepancy between the fossil record, morphological conclusions and evolutionary scenarios. According to many morphological works and phylogenetic reconstructions $[1,3,6-11]$, the hypothetical ancestor of tenebrionid beetles had the characters typical of the lagrioid branch and archaic Zolodininae (tentatively pimelioid branch). However, the oldest Tenebrionidae belong to the tenebrionoid lineage and only partly fit the 'lagriine' features (Table 3).

Table 3. Comparison of a hypothetical ancestor of darkling beetles [10] and latest Jurassic and early Cretaceous Tenebrionidae [31,41-43] (matching characters are marked with a grey background).

\begin{tabular}{|c|c|c|}
\hline No. & Hypothetical Lagrioid Ancestor * & $\begin{array}{l}\text { Oldest Fossil Tenebrionoid Darkling Beetle } \\
\text { (Alleculinae) }\end{array}$ \\
\hline 1 & Simple trichoid antennal sensilla & Mixed, compound, and simple trichoid antennal sensilla \\
\hline 2 & Longitudinal labrum & Transverse labrum \\
\hline 3 & $\begin{array}{l}\text { Internally and probably externally } \\
\text { open procoxal cavities }\end{array}$ & $\begin{array}{l}\text { Procoxal cavities closed externally and (at least in extant } \\
\text { taxa) internally }\end{array}$ \\
\hline 4 & Elytra with ten full striae & Elytra with nine striae and short scutellary striola \\
\hline 5 & Wings with medial fleck & $\begin{array}{l}\text { Unknown for fossil species. Extant Alleculinae without } \\
\text { median fleck, and Tenebrioninae without or with }\end{array}$ \\
\hline 6 & \multicolumn{2}{|c|}{$\begin{array}{l}\text { Groove along the outside edges of the abdominal ventrites, into which the elytral edges could } \\
\text { fit to produce a sealed subelytral cavity }\end{array}$} \\
\hline 7 & $\begin{array}{l}\text { Ovipositor with four coxites and } \\
\text { terminal styli }\end{array}$ & Ovipositor with four coxites and lateral styli \\
\hline \multirow{2}{*}{8} & \multirow{2}{*}{$\begin{array}{l}\text { Female genital tract with the } \\
\text { primary bursa copulatrix and } \\
\text { without spermatheca }\end{array}$} & $\begin{array}{c}\text { Alleculinae: unvisible in fossils } \\
\text { Extant taxa: female genital tract with primary or } \\
\text { secondary bursa copulatrix and without spermatheca }\end{array}$ \\
\hline & & $\begin{array}{l}\text { Alphitobiini: unvisible in fossils } \\
\text { Extant taxa: female genital tract without bursa copilatrix, } \\
\text { with spermatheca }\end{array}$ \\
\hline 9 & $\begin{array}{l}\text { Aedeagus without alae (extensions } \\
\text { of the apical piece) }\end{array}$ & $\begin{array}{l}\text { Aedeagus with alae (at least in } \\
\text { Platycteniopus diversoculatus) }\end{array}$ \\
\hline 10 & Defensive glands are absent & $\begin{array}{c}\text { Defensive glands are presented } \\
\text { (well visible intersegmental membranes between } \\
\text { abdominal ventrites } 3-5 \text { ) }\end{array}$ \\
\hline
\end{tabular}

* The ancestor is most closely related to the extant Belopini of the lagrioid branch and Zolodininae, tentatively in the
Pimeloid branch [10] and probably Kuhitangiinae of the pimelioid branch [13]

Thus, only two characters fit (character eight only partly fits) the hypothetical ancestor of darkling beetles. One additional dual character in the hypothetical ancestor is the open or closed mesocoxal cavity. Zolodininae, the most primitive Tenebrionidae that is similar to the hypothetical ancestor, have open mesocoxal cavities, but Belopini and Kuhitangiinae have closed ones. Matthews and Bouchard [10] (p. 35) assumed that "tenebrionoids would have branched off very soon thereafter" because Palorini of the tenebrionoid branch have many of the mentioned "ancestral" characters. In general, this hypothesis is supported by the fossil record, and also, it can be assumed that three main lineages of Tenebrionidae were branched during a short time period.

On the other hand, the oldest fossil Tenebrionidae has many characters $(1-5,7,10)$, which are currently interpreted as derived [1,10]. This discrepancy can be explained by gaps in the fossil record (especially in Jurassic deposits) and the earlier origin of Tenebrionidae, in Early Jurassic, as assumed by L. Medvedev [31] and Kergoat et al. [14]. In any case, taking into account the grounded monophyly 
of Tenebrionidae, the basal diversification (branching of the main lineages) of this family started at the earliest stages of the evolution of the darkling beetles.

\section{Conclusions}

The family Tenebrionidae is represented in the fossil record with 122 species, 78 genera (including 29 extinct genera) from seven subfamilies of three main branches in the time span of 201-11.6 Ma. This includes the lagrioid branch (Lagriinae, Nilioninae), pimelioid branch (Pimeliinae), and tenebrioid branch (Alleculinae, Tenebrioninae, Diaperinae, Stenochiinae). The most diverse records are reported in the Paleogene, Eocene (Geiseltal Halle, Baltic Amber, Florissant), and Miocene Dominican Amber. The oldest known distinct Mesozoic darkling beetles are from the Middle/Late Jurassic of Karatau (Alleculinae) and early Cretaceous of Yixian (Alleculinae and Tenebrioninae).

Darkling beetles of the tenebrionoid branch are the most diverse in the fossil record: Alleculinae: 30 species (since Middle Jurassic in the fossil record); Tenebrioninae: 28 species (since early Cretaceous in the fossil record); Stenochiinae: 21 species (since Middle Paleocene in the fossil record); Diaperinae: 15 species (since Middle Paleocene in the fossil record); lagrioid branch: 14 species: Lagriinae: 13 species, including an undescribed one (since late Cretaceous in the fossil record); Nilioninae: one species (since early Miocene in the fossil record).

Paleontological evidence partly suggests that the following evolutionary scenarios of Tenebrionidae occurred as indicated by Kergoat with co-authors [14]: (1) angiosperms had an insignificant impact on the diversification of tenebrionids, with the exception of diversification of the pimelioid branch during the Late Jurassic; (2) paleontological evidence supports the differentiation of the family at least by the Middle Jurassic, whether the ancestral forms of Tenebrionidae were xerophilic or mesophilic. Discrepancies between the hypothetical lagrioid ancestor of Tenebrionidae and the oldest known tenebrionoid fossils are possibly related to gaps in the fossil record.

Funding: The study was supported by the Russian Foundation for Basic Research (Grant 18-04-00243-A), partly by the basic research project Precaspian Institute of Biological Resources of the Daghestan Federal Research Centre of the Russian Academy of Sciences, registration number No. AAAA-A17-117081640018-5, the Program of the Presidium of the Russian Academy of Sciences: "Biodiversity of natural systems. Biological resources of Russia: state assessment and fundamental bases of monitoring".

Acknowledgments: The author is much obliged to Alexander G. Kirejtshuk (Zoological Institute of the Russian Academy of Sciences) for permanent help with material, productive discussions, valuable comments, and corrections, to Fabien Condamine (CNRS-UMR 5554 Institut des Sciences de l'Evolution (Université de Montpellier), France), George Poinar (Oregon State University, USA), and two anonymous reviewers for helpful comments, discussion, and corrections.

Conflicts of Interest: The author declares no conflict of interest.

\section{References}

1. Matthews, E.G.; Lawrence, J.F.; Bouchard, P.; Steiner, W.E.; Ślipiński, S.A. 11.14. Tenebrionidae Latreille, 1802. In Handbook of Zoology. Arthropoda: Insecta. Part 38. Coleoptera, Beetles. Vol. 2. Morphology and Systematics (Elateroidea, Bostrichiformia, Cucujiformia Partim); Leschen, R.A.B., Beutel, R.G., Lawrence, J.F., Eds.; Walter de Gruyter: Berlin, Germany, 2010; pp. 574-659.

2. Kergoat, G.J.; Soldati, L.; Clamens, A.L.; Jourdan, H.; Zahab, R.; Genson, G.; Bouchard, P.; Condamine, F.L. Higher-level molecular phylogeny of darkling beetles (Coleoptera, Tenebrionoidea, Tenebrionidae). Syst. Entomol. 2014, 39, 486-499. [CrossRef]

3. Watt, J.C. A revised subfamily classification of Tenebrionidae (Coleoptera). New Zealand J. Zool. 1974, 1, 381-452. [CrossRef]

4. Medvedev, G.S. Taxonomic significance of antennal sensilla of darkling beetles (Coleoptera, Tenebrionidae). In Trudy Vsesoyuznogo Entomologisheskogo Obshchestva. Vol. 58. Morphological Bases of the Systematics of Insects; Medvedev, G.S., Ed.; Nauka: Leningrad, Russia, 1977; pp. 61-86. (In Russian)

5. Doyen, J.T. Familial and subfamilial classification of the Tenebrionoidea (Coleoptera) and a revised generic classification of the Coniontini (Tentyriidae). Quaest. Entomol. 1972, 8, 357-376. 
6. Doyen, J.T. Cladistic Relationships among Pimeliine Tenebrionidae (Coleoptera). J. N. Y. Entomol. Soc. 1993, 101, 443-514.

7. Doyen, J.T.; Lawrence, J.F. Relationships and higher classification of some Tenebrionidae and Zopheridae (Coleoptera). Syst. Entomol. 1979, 4, 333-337. [CrossRef]

8. Tschinkel, W.R.; Doyen, J.T. Comparative anatomy of the defensive glands, ovipositors and female tubes of tenebrionid beetles (Coleoptera). Int. J. Insect Morphol. Embryol. 1980, 9, 321-368. [CrossRef]

9. Doyen, J.T.; Tschinkel, W.R. Phenetic and cladistic relationships among tenebrionid beetles (Coleoptera). Syst. Entomol. 1982, 7, 127-183. [CrossRef]

10. Matthews, E.G.; Bouchard, P. (Eds.) Tenebrionid Beetles of Australia: Descriptions of Tribes, Keys to Genera, Catalogue of Species; Australian Biological Resources Study: Canberra, Australia, 2008; pp. 1-410.

11. Aalbu, R.L.; Triplehorn, C.A.; Campbell, J.M.; Brown, K.W.; Somerby, R.E.; Thomas, D.B. Tenebrionidae Latreille 1802. In American Beetles, Vol. 2. Polyphaga: Scarabaeoidea through Curculionoidea; Arnett, R.H.J., Thomas, M.C., Skelley, P.E., Frank, J.H., Eds.; CRC Press: New York, NY, USA, 2002; pp. 463-509.

12. Bouchard, P.; Lawrence, J.F.; Davies, A.E.; Newton, A.F. Synoptic classification of the world Tenebrionidae (Insecta: Coleoptera) with a review of family-group names. Ann. Zool. 2005, 55, 499-530.

13. Nabozhenko, M.V.; Sadeghi, S. Foranotum perforatum gen. et sp. nov.-A new troglobitic darkling beetle (Coleoptera: Tenebrionidae: Kuhitangiinae: Foranotini trib. nov.) from a cave in Southern Zagros, Iran. Zootaxa 2017, 4338, 163-172. [CrossRef]

14. Kergoat, G.L.; Bouchard, P.; Clamens, A.L.; Abbate, J.L.; Jourdan, H.; Jabbour-Zahab, R.; Genson, G.; Soldati, L.; Condamine, F.L. Cretaceous environmental changes led to high extinction rates in a hyperdiverse beetle family. BMC Evol. Biol. 2014, 14, 220. [CrossRef]

15. Zhang, S.Q.; Che, L.H.; Li, Y.; Liang, D.; Pang, H.; Ślipiński, A.; Zhang, P. Evolutionary history of Coleoptera revealed by extensive sampling of genes and species. Nat. Commun. 2018, 9, 205. [CrossRef] [PubMed]

16. Germar, E.F. (Ed.) Insectorum Protogaeae Specimen Sistens Insecta Carbonum Fossilium. Fauna Insectorum Europae. Fasc. 19; Kümmelii: Halae, CA, USA, 1837; pp. 1-27. [CrossRef]

17. Heyden, C.V. Fossile Insekten aus der Rheinischen Braunkhohle. Palaeontographica. 1859, 8, 1-15.

18. Heyden, C.V.; Heyden, L.V. Käfer und Polypen aus der Braunkohle des Siebengebirges. Palaeontographica 1866, 15, 131-156.

19. Heer, O. Die Insektenfauna der Tertiargebilde von Oeningen und von Radoboj in Croatien. Erste Theil. Kaefer. Neue Denkschriften der Allgemeinen. Schweiz. Ges. Naturw. 1847, 8, 1-230.

20. Heer, O. (Ed.) Die Urwelt der Schweiz; Schulthess: Zürich, Switzerland, 1865; pp. 1-622.

21. Heer, O. Primitiae florae fossilis sachalinensis. Mém. Acad. Sci. St. Pétersb., VIIe Sér. 1878, 25, 1-61.

22. Heer, O. (Ed.) Ueber die fossilen Insekten Grönlands. In Die Fossile Flora Grönlands 2; Wurster, J. \& Co: Zurich, Switzerland, 1883; pp. 143-148.

23. Scudder, S.H. Appendix A. The fossil insects collected in 1877, by Mr. G.M. Dawson, in the interior of British Columbia. In Report of Progress of the Geological Survey of Canada 1877-1878; Dawson Brothers: Ottawa, ON, Canada, 1879; pp. 175-185.

24. Scudder, S.H. Adephagous and Clavicorn Coleoptera from the Tertiary Deposits at Florissant, Colorado with Descriptions of a Few Other Forms and a Systematic List of the Non-Rhynchophorus Tertiary Coleoptera of North America; Monogr. U. S. Geol. Surv.; US Government Printing Office: Washington, DC, USA, 1900; Volume 40, pp. 1-148.

25. Wickham, H.F. New Fossil Coleoptera from Florissant. Am. J. Sci. 1909, 28, 126-130. [CrossRef]

26. Wickham, H.F. New fossil Coleoptera from Florissant, with notes on some already described. Am. J. Sci. 1910, 29, 47-51. [CrossRef]

27. Wickham, H.F. Fossil Coleoptera from Florissant in the United States National Museum. Proc. U. S. Nat. Mus. 1913, 45, 283-303. [CrossRef]

28. Wickham, H.F. New Miocene Coleoptera from Florissant. Bull. Mus. Comp. Zool. 1914, 53, $423-494$.

29. Klebs, R. Über Bernsteineinschlüsse in allgemeinen und die Coleopteren meiner Bernsteinsammlung. Schrift. Physikal. Ökonom. Gesell. Königsb. 1910, 51, 217-242.

30. Haupt, H. Die Käfer (Coleoptera) aus der eozänen Braunkohle des Geiseltales. Geologica 1950, 6, 1-168.

31. Medvedev, L.N. New Mesozoic beetles (Cucujoidea) of Asia. Paleontol. Zhurnal 1969, 1, 119-125. (In Russian)

32. Larsson, S.G. (Ed.) Baltic Amber-A Palaeobiological Study: Entomonograph, Volume 1; Scand. Sci. Press Ltd.: Klampenborg, Denmark, 1978; pp. 1-192. 
33. Hieke, F.; Pietrzeniuk, E. Die BernsteinKäfer des Museums für Naturkunde, Berlin (Insecta, Coleoptera). Mitt. Zool. Mus. Berl. 1984, 60, 297-326.

34. Spahr, U. (Ed.) Systematischer Katalog der Bersteinund Kopal-Käfer (Coleoptera); Staatliches Museum für Naturkunde: Karlsruhe, Germany, 1981; Volume 80, pp. 1-107.

35. Hong, Y.C. (Ed.) Fossil Insects, Scorpionids and Araneids in the Diatoms of Shanwang; Geological Publishing House: Beijing, China, 1985; pp. 1-113.

36. Zhang, J.F. (Ed.) Fossil Insects from Shanwang, Shandong, China; In Chinese with English Summary; Shandong Science \& Technology Press: Jinan, China, 1989; pp. 1-459.

37. Kaszab, Z.; Schawaller, W. Eine neue Schwarzkäfer-Gattung und -Art aus Dominikanischem Bernstein (Coleoptera, Tenebrionidae). Stutt. Beitr. Nat. Ser. B (Geol. Palaeontol.) 1984, 109, 1-6.

38. Doyen, J.T.; Poinar, G.O. Tenebrionidae from Dominican amber (Coleoptera). Entomol. Scand. 1994, 25, $27-51$. [CrossRef]

39. Kirejtshuk, A.G.; Merkl, O.; Kernegger, F. A new species of the genus Pentaphyllus Dejean, 1821 (Coleoptera, Tenebrionidae, Diaperinae) from the Baltic amber and checklist of the fossil Tenebrionidae. Zoosyst. Rossica 2008, 17, 131-137.

40. Kirejtshuk, A.G.; Ponomarenko, A.G. Taxonomic List of Fossil Beetles of the Surder Scarabaeina (Part 3). Available online: https://www.zin.ru/Animalia/Coleoptera/rus/paleosy2.htm (accessed on 10 May 2018). (In Russia)

41. Kirejtshuk, A.G.; Nabozhenko, M.V.; Nel, A. First Mesozoic representative of the subfamily Tenebrioninae (Coleoptera, Tenebrionidae) from the Lower Cretaceous of Yixian (China, Liaoning). Entomol. Obozr. 2011, 90, 548-552. [CrossRef]

42. Nabozhenko, M.V.; Chang, H.; Xu, L.; Pu, H.; Jia, S. A new species and a new genus of comb-clawed beetles (Coleoptera: Tenebrionidae: Alleculinae) from Lower Cretaceous of Yixian (China, Laoning). Paleontol. J. 2015, 49, 1420-1423. [CrossRef]

43. Chang, H.L.; Nabozhenko, M.; Pu, H.Y.; Xu, L.; Jia, S.H.; Li, T.R. First record of fossil comb-clawed beetles of the tribe Cteniopodini (Insecta: Coleoptera: Tenebrionidae) from the Jehol Biota (Yixian formation of China), Lower Cretaceous. Cretac. Res. 2016, 57, 289-293. [CrossRef]

44. Nabozhenko, M.V.; Kirejtshuk, A.G. Cryptohelops menaticus-A new genus and species of the tribe Helopini (Coleoptera: Tenebrionidae) from the Paleocene of Menat (France). C. R. Palevol 2014, 13, 65-71. [CrossRef]

45. Nabozhenko, M.V.; Kirejtshuk, A.G. The oldest opatrine terrestrial darkling beetle (Coleoptera: Tenebrionidae: Tenebrioninae) from the Paleocene of Menat (France). Paläontol. Z. 2017, 91, 307-313. [CrossRef]

46. Kirejtshuk, A.G.; Nabozhenko, M.V.; Nel, A. New genus and species of the tribe Opatrini (Coleoptera, Tenebrionidae, Tenebrioninae) from the Lowermost Eocene amber of Paris Basin. Proc. Zool. Inst. RAS 2010, 314, 191-196.

47. Alexeev, V.I.; Nabozhenko, M.V. A new fossil tenebrionid beetle of the tribe Palorini (Coleoptera: Tenebrionidae) from Eocene Baltic Amber. Coleopt. Bull. 2015, 69, 127-130. [CrossRef]

48. Alekseev, V.I.; Nabozhenko, M.V. Palorus platycotyloides sp.n., the second fossil representative of the tribe Palorini (Coleoptera: Tenebrionidae) from Baltic Amber. Acta Zool. Bulg. 2017, 69, 167-170.

49. Nabozhenko, M.V.; Perkovsky, E.E.; Chernei, L.S. A new species of the genus Nalassus Mulsant (Coleoptera: Tenebrionidae: Helopini) from the Baltic amber. Paleontol. J. 2016, 50, 947-952. [CrossRef]

50. Nabozhenko, M.V.; Kirejtshuk, A.G.; Merkl, O. Yantaroxenos colydioides gen. and sp.n. (Tenebrionidae: Lagriinae) from Baltic Amber. Ann. Zool. 2016, 66, 563-566. [CrossRef]

51. Nabozhenko, M.V.; Bukejs, A.; Telnov, D. Gonialaenini, a new tribe of Lagriinae (Coleoptera: Tenebrionidae) from Eocene Baltic Amber. Zootaxa 2019, 4565, 253-260. [CrossRef]

52. Nabozhenko, M.; Chigray, I.; Bukejs, A. Taxonomic notes on the Eocene Helopini, and a review of the genus Isomira Mulsant, 1856 from Baltic amber (Coleoptera: Tenebrionidae). Insect Syst. Evol. 2019, 1, 1-15. [CrossRef]

53. Soldati, F.; Nabozhenko, M. Asida groehni sp. nov., the first and the oldest fossil representative of the subfamily Pimeliinae from Eocene Baltic amber (Coleoptera: Tenebrionidae: Asidini). Ann. Zool. 2017, 67, 555-559. [CrossRef]

54. Nabozhenko, M.V.; Chigray, I.A. New and little known species of Alleculini (Coleoptera: Tenebrionidae: Alleculinae): extinct from Eocene Baltic Amber and extant from Lebanon. Cauc. Entomol. Bull. 2018, 14, 171-176. [CrossRef] 
55. Telnov, D.; Bukejs, A.; Merkl, O. Description of a new fossil Statira Lepeletier et Audinet-Serville, 1828 (Coleoptera: Tenebrionidae: Lagriinae) from Baltic amber of the Sambian Peninsula. Zootaxa 2019, 4683, 508-514. [CrossRef] [PubMed]

56. Vitali, F. A new species of Corticeus Piller \& Mitterpacher, 1783 from Dominican amber (Coleoptera Tenebrionidae). Entomapeiron (P.S.) 2007, 2, 1-6.

57. Vitali, F. A new species of Tyrtaeus Champion, 1913 from Dominican amber (Coleoptera Tenebrionidae). Entomapeiron (P.S.). 2008, 3, 11-16.

58. Kirejtshuk, A.G.; Nel, A.; Kirejtshuk, P.A. Taxonomy of the reticulate beetles of the subfamily Cupedinae (Coleoptera: Archostemata), with a review of the historical development. Invertebr. Zool. 2016, 13, 61-190. [CrossRef]

59. Batelka, J.; Engel, M.S.; Prokop, J. A remarkable diversity of parasitoid beetles (Ripiphoridae) in Cretaceous amber, with a summary of the Mesozoic record of Tenebrionoidea. Cretac. Res. 2018, 90, 296-310. [CrossRef]

60. Arillo, A.; Ortuño, V. Catalogue of fossil insect species described from Dominican amber (Miocene). Stuttg. Beiträge Nat. B (Geol. Palaeontol.) 2005, 352, 1-68.

61. Handlirsch, A. (Ed.) Die Fossilen Insekten und Die Phylogenie der Rezenten Formen. Ein Handbuch für Paläontologen und Zoologen Vol. 1, lfg. I-IV.; Verlag von Wilhelm Engelmann: Leipzig, Germany, 1906; pp. 1-640.

62. Bachofen-Echt, A. (Ed.) Der Bernstein und Seine Einschlüsse; Springer: Wien, Austria, 1949; pp. 1-204.

63. Abdullah, M. New heteromerous beetles (Coleoptera) from the Baltic amber of eastern Prussia and gum copal of Zanzibar. Trans. R. Entomol. Soc. Lond. 1964, 116, 329-349. [CrossRef]

64. Yu, Y.; Liu, Z.H.; Shih, C.H.; Ren, D. Coleoptera-Beetles. In Rhythms of Insect Evolution: Evidence from the Jurassic and Cretaceous in Northern China, 1st ed.; Ren, D., Shih, C.H.K., Gao, T., Yao, Y.U., Wang, Y., Eds.; John Wiley \& Sons, Ltd.: Hoboken, NJ, USA, 2019; pp. 337-428. [CrossRef]

65. Seidlitz, G. Alleculidae. In Naturgeschichte der Insecten Deutschlands. Erste Abtheilung. Coleoptera. Fünfter Band. Zweite Hälfte. Lieferungen 1-3; Erichson, W.F., Ed.; Nicolaische Verlags-Buchhandlung: Berlin, Germany, 1896; pp. 1-305.

66. Campbell, J.M. Fossil beetle of the genus Hymenorus (Coleoptera: Alleculidae) found in amber from Chiapas, Mexico. Univ. Calif. Publ. Entomol. 1963, 31, 41-42.

67. Schaufuss, L.W. Einige Käfer aus dem baltischen Bernsteine. Berl. Entomol. Z. 1888, 32, 266-270. [CrossRef]

68. Bousquet, Y.; Bouchard, P.; Campbell, J.M. Catalogue of the genus-group names in Alleculinae (Coleoptera: Tenebrionidae). Coleopt. Bull. 2015, 69, 131-151. [CrossRef]

69. Berendt, G.C. (Ed.) Die im Bernstein befi Ndlichen Organischen Reste der Vorvelt; Nikolaische Buchhandlung: Danzig, Poland, 1845; pp. 1-38.

70. Scudder, S.H. (Ed.) Index to the Known Fossil Insects of the World including Myriapods and Arachnids; US Government Printing Office: Washington, DC, USA, 1891; Volume 71, pp. 1-744. [CrossRef]

71. Seidlitz, G.V. Nachträge und Berichtigungen zur Familie Tenebrionidae. In Naturgeschichte der Insecten Deutschlands. Erste Abteilung Coleoptera. Bd. 5. Hf. 8; Kiesenwetter, H.V., Seidlitz, G.V., Eds.; Nicolaische Verlags-Buchhandlung: Berlin, Germany, 1898; pp. 813-853.

72. Deutschlands Petrefacten: Ein Systematisches Verzeichniss Aller in Deutschland und den Angrezenden Ländern Vorkommenden Petrefacten, Nebst Angabe der Synonymen und Fundorte; Giebel, C.G. (Ed.) Verlag von Ambrosius Abel: Leipzig, Germany, 1852; pp. 1-706.

73. Giebel, C.G. (Ed.) Fauna der Vorwelt Mit steter Berücksichtigung der Lebenden Thiere. Monographisch Dargestellt. B. 12; F.A. Brockhaus: Leipzig, Germany, 1856; pp. 1-511. [CrossRef]

74. Scudder, S.H. (Ed.) Canadian Fossil Insects, Myriapods and Arachnids, 2. The Coleoptera Hitherto Found Fossil in Canada; Contributions to Canadian Palaeontology; Geolog. Surv.: Ottawa, ON, Canada, 1895; Volume 2, pp. 27-56.

75. Scudder, S.H. (Ed.) Systematic Review of our Present Knowledge of Fossil Insects including Myriapods and Arachnids; Govt. Print. Off.: Washington, DC, USA, 1886; Volume 31, pp. 1-128. [CrossRef]

76. Scudder, S.H. The tertiary insects of North America. Rep. United States Geol. Surv. territories. 1890, 13, 1-734. [CrossRef]

77. Heyden, C.V. Gliederthiere aus der Braunkohle des Niederrhein's, der Wetterau und der Röhn. Palaeontographica 1862, 10, 62-82.

78. Hörnschemeyer, T. Ein fossiler Tenebrionide Ceropria? messelense n. sp. (Coleoptera: Tenebrionidae: Diaperinae) aus dem Mitteleozän der Grube Messel bei Darmstadt. Cour. Forsch. Senckenberg 1994, 170, 75-83. 
79. Hope, F.W. Observations on succinic insects. Trans. R. Entomol. Soc. Lond. 1837, 2, 46-57. [CrossRef]

80. Meunier, F. Die Insektenreste aus dem Lutetien von Messel bei Darmstadt. Abh. Grösshesz. Hess. Geol. Landesanst. 1921, 7, 2-15.

81. Pongrácz, A. Die eozäne Insektenfauna des Geiseltales. Nova Acta Leopold. 1935, 2, 485-572.

82. Heyden, C.V.; Heyden, L.V. Fossile Insekten aus der Braunkohle von Salzhausen. Palaeontographica 1865, 14, 31-35.

83. Cockerell, T.D.A. Fossil Arthropods in the British Museum, III. Ann. Mag. Nat. Hist. 1920, 6, 65-72. [CrossRef]

84. Redtenbacher, L. Helops atticus. In Unger F. Die Fossile Flora Von Kumi Auf Der Insel Euboea. Denkschr. Österr. Akad. Wiss. Math. Naturwiss. Kl. 1867, 27, 33.

85. Vitali, F. Systematic revision of the fossil cerambycids from Geiseltal (Coleoptera Cerambycidae). Entomapeiron (PS). 2008, 3, 1-10.

86. Wang, B.; Zhang, H. The oldest Tenebrionoidea (Coleoptera) from the Middle Jurassic of China. J. Paleontol. 2011, 85, 266-270. [CrossRef]

87. Shchegoleva-Barovskaya, T.I. Der erste Vertreter der Familie Mordellidae (Coleoptera) aus der Juraformation Turkestans. CR Acad. Sci. URSS 1929, 1, 25-29.

88. Hsiao, Y.; Yu, Y.; Deng, C.; Pang, H. The first fossil wedge-shaped beetle (Coleoptera, Ripiphoridae) from the middle Jurassic of China. Eur. J. Taxon. 2017, 277, 1-13. [CrossRef]

89. Krishtofovich, A.N. (Ed.) Paleobotany; Gostoptehizdat: Leningrad, Russia, 1957; pp. 1-650. (In Russian)

90. Kirejtshuk, A.G. The Himalaya: Region of relicts and center of modern diversifications of biota by example of sap-beetles (Coleoptera, Nitidulidae). In Russian Himalayan Research: Past, Present, Future; Borkin, L.J., Ed.; Evropeisky Dom: St Petersburg, Russia, 2017; pp. 168-172.

91. Striganova, B.R. Morphological peculiarities of and identification key to alleculid-larvae of the subfamily Alleculinae (Coleoptera). Zool. Zhurnal 1961, 40, 193-200. (in Russian).

92. Dubrovin, N.N.; Kompantseva, T.V. Morpho-ecological review of larvae of Isomira (Coleoptera, Alleculidae) with the description of a new species from Central Asia. Zool. Zhurnal 1992, 71, 14-22. (In Russian)

93. Nabozhenko, M.V. A revision of the genus Catomus Allard, 1876 and the allied genera (Coleoptera, Tenebrionidae) from the Caucasus, Middle Asia, and China. Entomol. Rev. 2006, 86, 1024-1072. [CrossRef]

94. Nabozhenko, M.V. Darkling Beetles of the Tribe Helopini (Coleoptera: Tenebrionidae) of the World Fauna. Ph.D. Thesis, Zoological Institute of the Russian Academy of Sciences, St Petersburg, Russia, 2019; pp. 1-408. (In Russian).

95. Kirejtshuk, A.G.; Nel, A. Current knowledge of Coleoptera (Insecta) from the Lowermost Eocene Oise amber. Insect Syst. Evol. 2013, 44, 175-201. [CrossRef]

96. Kohlman-Adamska, A. A graphic reconstruction of an "amber" forest. In The Amber Treasure Trove, Pt I: The Tadeusz Giecewiczs Collection at the Museum of the Earth, Polish Academy of Sciences, Warsaw; Kosmowska-Ceranowicz, B., Ed.; Oficyna Wydawnicza Sadyba: Warsaw, Poland, 2001; pp. 15-17.

97. Alekseev, V.; Alexeev, P. New Approaches for Reconstruction of the Ecosystem of an Eocene Amber Forest. Biol. Bull. 2016, 43, 75-86. [CrossRef]

98. Poinar, G.; Brown, A.E. Descriptions of a broad-nosed weevil (Eudiagogini: Curculionidae) and false ladybird beetle (Nilionini: Nilionidae) in Dominican amber. Hist. Biol. 2011, 23, 231-235. [CrossRef]

99. Aloquio, S.; Lopes-Andrade, C. Redescription of Immature Stages and Adults of Nilio (Nilio) brunneus (Coleoptera: Tenebrionidae: Nilioninae). Zoologia 2016, 33, e20150191. [CrossRef]

(C) 2019 by the author. Licensee MDPI, Basel, Switzerland. This article is an open access article distributed under the terms and conditions of the Creative Commons Attribution (CC BY) license (http://creativecommons.org/licenses/by/4.0/). 